\title{
English Animation Dubbing Based Techniques and Iranian Intermediate EFL Learners' Nativelike Pronunciation Development
}

\author{
Pooneh Karimzadeh \\ Department of Foreign language, Payame Noor University, I. R. of Iran \\ Tel: 98-21-4461-1470Ｅ-mail: pooneh.karimzadeh@gmail.com
}

\begin{abstract}
Maryam Rezaei Ghahroudi
Department of language, Islamic Azad University of Iran, Science and Research Branch

Tel: 98-21-221-9032Ｅ-mail: rezaei_m53@yahoo.com
\end{abstract}

Received: April 15, 2017 Accepted: May 2, 2017 Published: May 4, 2017

doi:10.5296/ijele.v5i2.11175 URL: https://doi.org/10.5296/ijele.v5i2.11175

\begin{abstract}
This research was an attempt to investigate the remarkable dubbing techniques that can improve communicative competence to achieve appropriate level of speaking abilities. The growth of technology increases the need for learning an international language. Because of this learners tend to improve their speaking abilities specifically the suprasegmental features that can shed light on the quality of their interaction and communication. Since EFL learners' muscles need to be well developed to produce the new words of the target language, pronunciation becomes so difficult. The main focus of this study was the investigation of a great deal of variety in the dubbing techniques that lead to more rehearsal, high motivation, self-confident and more successful English speakers. In order to investigate the relationship between dubbing and improved suprasegmental features, 24 homogeneous intermediate 10-15 year old learners were chosen from 40 randomly by an oral test that was divided to two sub groups, i.e,12 in experimental who received treatment and 12 in control group without that. Students took posttest orally and their performances were recorded and investigated. The result of data analysis indicated that dubbing based strategies have a significant influence on native like pronunciation development.
\end{abstract}

Keywords: dubbing, suprasegmental, stress, intonation, repetition, rehearsal 


\section{Introduction}

The speed of growth of technology all around the world is remarkably incredible. Fortunately increasing day to day people's eagerness for acquiring new technology academically and professionally is evident in Iran. Every moment in Iran, the majority of people eagerly participates in English classes and tries to improve their main four language skills. There are not few hard working, talented and intelligent students in gifted schools, who try to take control of their speaking skills. For this reason they take advantage of different speaking classes in Institutes.

\subsection{Background and Purpose}

Pronunciation is a controversial aspect of speaking. Audiolingualism's main focus was on imitation and drills, but nowadays it has been investigated that effective learning should be beyond the simple imitation and based on the more meaningful, communicative practice (Pinnington, 1996). Today teaching pronunciation consists of increasing awareness of the communicative function of suprasegmental features in spoken discourse. (Brazil, 1980)

As a matter of fact non-native pronunciation can be identified easily everywhere and unfortunately it may cause some undesirable consequences (Fledge, 1995). Non-native users of language refer to those who tend to transfer intonation, phonological process and pronunciation from L1 to L2. In order to have native like pronunciation, a learner should control the degree of first language transfer and improve the pronunciation of specific sounds as well as prosodic_features of language such as stress and intonation and should be more exposed to the nativelike input. (Rodney H. Jones, 1997)

Nowadays watching movies as an amusing teaching technique on one hand has significant role in learning language naturally and on the other hand is more influential on speaking than traditional strategies (Yi-hui Chiu, 2012). When hard grammar and vocabulary become exhausting, watching movies and animation in English is a significant way of improving your English speaking and listening skills. In dubbing movie classes, you can listen to movie dialogue and try to report those utterances and sentences. Furthermore teachers draw students' attention toward the language of the plot of the animation story and by listening and repetition they try to achieve the appropriate level of the natural accent and fluency. In this process of practice and rehearsal, learners are capable to improve their pronunciation. According to $\mathbf{J}$ Burston (2005) dubbing provides various types of strategies that can improve different skills in language learning. Of course this kind of research has been done before but the few of them are available such as a research by Yi-hui Chiu (2012) who has investigated the dubbing projects positive effect in EFL classes that can facilitate the learner's English pronunciation acquisition. Using extraordinary dubbing-based instructions in EFL classes in the most of Iranian pedagogical setting are unknown. Because of this, writers' main aim of presenting this article is to further investigation of the efficient dubbing-based strategies and its significant role in Iranian intermediate EFL learning process.

\subsection{Significant of the Study}

This paper represents the investigation of the impressive and efficient techniques of dubbing 
based instruction which teacher can bring in to use in their EFL classes as pedagogical tools. In order to modernize teaching methods in classrooms, audiovisual devices can be utilized to present movie, slide show and dubbing. Watching movies has significant role in learning language especially pronunciation improving. Utilizing dubbing techniques as pedagogical tools make high_motivated, self-confidant and more successful English speakers. More over The symmetrical role of a teacher increases the degree of cooperation, unanimity and harmony. Dubbing-based strategy (DBS) consists of some specification that can be summarized by "10 I" as follows:

Table 1.

\begin{tabular}{|c|c|}
\hline \multirow{10}{*}{$\begin{array}{l}10 \\
\text { DBS I } \\
\text { specificati } \\
\text { ons }\end{array}$} & 1.Input frequency \\
\hline & 2.Increasing amount of learners' repetition-rehearsal(RR) \\
\hline & 3.Intensive pre-arranged course \\
\hline & 4.Instruction is pre-planned \\
\hline & 5.Integration of receptive skills as the first phase(listening-reading) \\
\hline & 6.Involve learner in a naturally emotional context \\
\hline & 7.Interactionally dynamic group work \\
\hline & 8.Intentionally high attention and awareness \\
\hline & $\begin{array}{l}\text { 9.Intrinsic motivation as the learners "nature of the motivation in dubbing } \\
\text { class }\end{array}$ \\
\hline & $\begin{array}{l}\text { 10. Interweaving suprasegmental features such as stress and intonation with } \\
\text { gestures, mime, facial expressions and body postures when learners } \\
\text { synchronize their voice with characters' voice. }\end{array}$ \\
\hline
\end{tabular}

\subsection{Statement of the Problem}

In spite of the extended teachers' attempt at improving the quality of EFL learners' pronunciation, unfortunately some of the Iranian learners can't apply the appropriate and standard level of native like pronunciation. The reason can be summarized as follows:

1. Low learners' participation in interactions lead to inability to apply oral communication properly.

2. Using one's mother tongue a lot in the class.

3. Lack of the acceptable amount of degree of communicative skills.

4. Lack of enough practice. According to lui and Little Wood (1997), the more learners practice the language the more they can use their communicative skill.

5. Other factors such as culture, anxiety, fear of peer reaction, fear of teacher punishment, L1 


\section{Macrothink

transfer, introversion, and even lack of enough motivation.

\subsection{Research Question and Hypothesis}

Concerning the problem stated above, the following question can be mentioned:

Q1: Do English animation dubbing based techniques have any effect on the improvement of the Iranian intermediate EFL learners' native-like pronunciation?

Based on the research question presented above, hypothesis is proposed:

H01: English animation dubbing based techniques don't have any effect on the improvement of the Iranian intermediate EFL learners' native-like pronunciation.

\section{Review of Literature}

\subsection{Pronunciation}

The act or result of producing the sounds of speech, including articulation, stress, and intonation.

\subsection{Stress and Intonation}

Word stress emphasis on certain syllables in a word and sentence stress emphasis on certain words in a sentence. Intonation consists of rising and falling of our voice as we speak.

\subsection{Dubbing}

Dubbing is acting as a 'voice-over' actor. Active dubbing is an audiovisual process by which the original speaker's voice is replaced entirely by our student's voice. (Talavan,2013)

\subsection{Prosody}

It refers to those elements of speech that on one hand are not individual phonetic and on other hand are properties of syllable and larger units of speech which consists of intonation, tone, stress and rhythm. It also has considerable role in expressing emotion and reflecting verity of features and form of the sentences.

\subsection{How Can Dubbing Be Influential?}

Since the main aim of teaching speaking is to achieve proper level of communicative competence (Celce-Marcia and Olshtain 2013), Dubbing-based strategies (DBS) can improve prosodic features language that leads to better pronunciation. According to Javier, Ávila \& Noa, Talaván (2013), dubbing as a pedagogical tool improve oral skills and involve other skills and activities as follows (Fig. 1): 


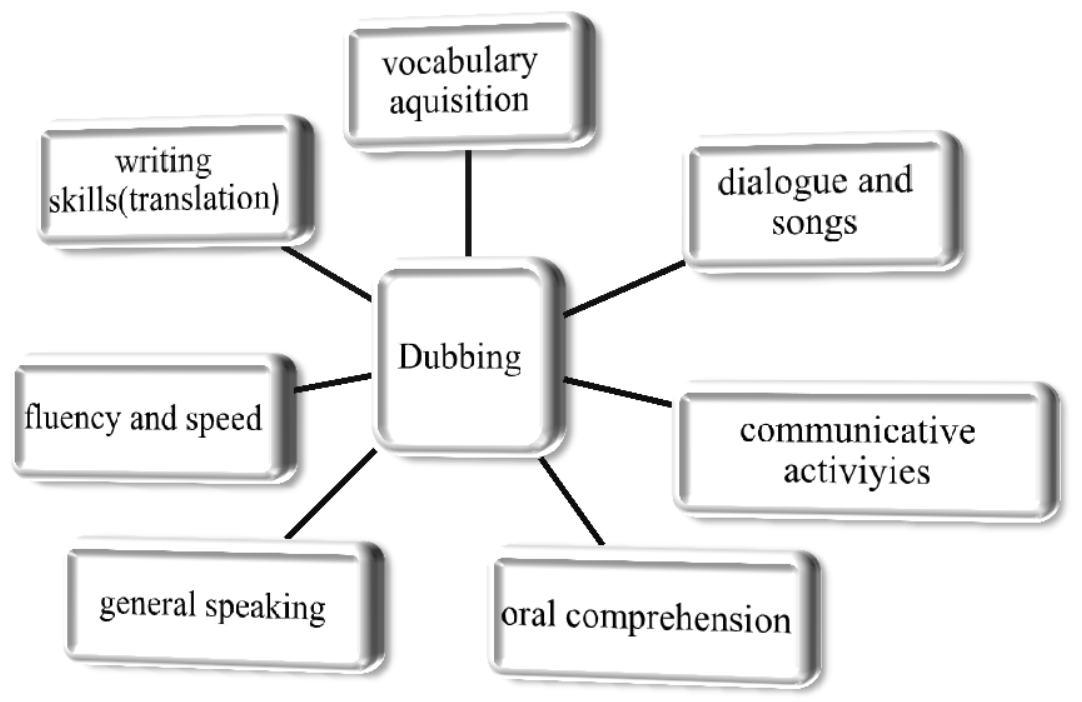

Figure 1. dubbing as a pedagogical tool improve oral skills and involve other skills and activities as follows

\section{Methodology}

\subsection{Participants}

A total of 60 students participated in speaking classes in a private English institute in Iran in the summer 2016.40 students tend to participate in movie-speaking $\mathrm{cl}$ asses, so based on an oral-exam, interview and their background English knowledge as a pretest 24 homogenous ones are chosen (all of them has a background of at least 3 year institutional English course). Their ages are between 11-15 years old. This group are divided two sub group randomly, i.e, 12 students in experimental group that is dubbing-movie class and 12 ones in control group that is just movie-class.

The supervisor and the manager of the institute observe these classes and receive reports and records from the teacher. The learners' interaction and motivation are getting better and better.

It is necessary to mention that one of the creative, willful and experienced student (17 years old, writer's student) as a young dubber, has a significant role in this project.

\subsection{Instrumentation}

The pre-test consists of the oral exam, interview and each students' background knowledge and the number of terms that they have passed in the institute. In the movie class the computer is available to watch animation, poster and PowerPoints are also applied. In dubbing-movie class computer, slide show and voice-recorder are used. The whole course takes about 3 months, one day a week; each session takes 1 and half an hour practice and rehearsal. 


\section{Macrothink}

1. As posttest, teacher records the oral performance of each student and after that session, teacher, manager and supervisor observe the recorded voice and film. Of course as the team work feedback and result, the whole dubbing work is recorded and investigated.

2. The sub-titled inside-out famous animation is used .The dubbing class learners also use some sheet to take note and write the animation text for further practice.

3. The role of a teacher as a friend increases the degree of cooperation and learning.

4. The pictures of famous animation characters are on the wall, and students try to imitate their figures and dressing.

5. Every session students' voice is recorded. They listen to their voice and teacher monitors them and help them to improve and remove their oral speech utterances; pronunciation, intonation and fluency.

\subsection{Data Collection and Procedures}

In movie-speaking class as control group teacher draws learner's attention to watch the movie and listen to the dialogues carefully after 1 minute, teacher pause it and asks:

"What did you see?

What did you understand?

Can you describe ...?"

Students' answers would be like this:

"I saw jungle. People were happy. The bad man was angry...."

Sometimes after two or three sentences, teacher pauses and students should repeat that sentences. The students should make power points for the animation plot, too. In the second group; dubbing class as experimental group, these procedures can be followed:

Table 2.

1. Teachers chooses the sub-titled animation

2. Teacher breaks up the film (about 20 minutes of it)

3. Using the text of the plot or sub-titles to facilitate the process of comprehension

4. At first students watch movie once and get the gist

5. Then teacher writes the problematic vocab and structures on the board and explain them

6. Teacher plays the film again ,pause and students repeat the sentences

7. In the case of occurring problem, Teacher goes back to the problematic sentences and they practice more 
8. The process of watching animation(WA)-listening(L)-sub title reading (SR)-repetition/rehearsal(RR), continues until learner can take control of their speaking skills (Fig.5)

9. This cycle of WALS3R continues for several times

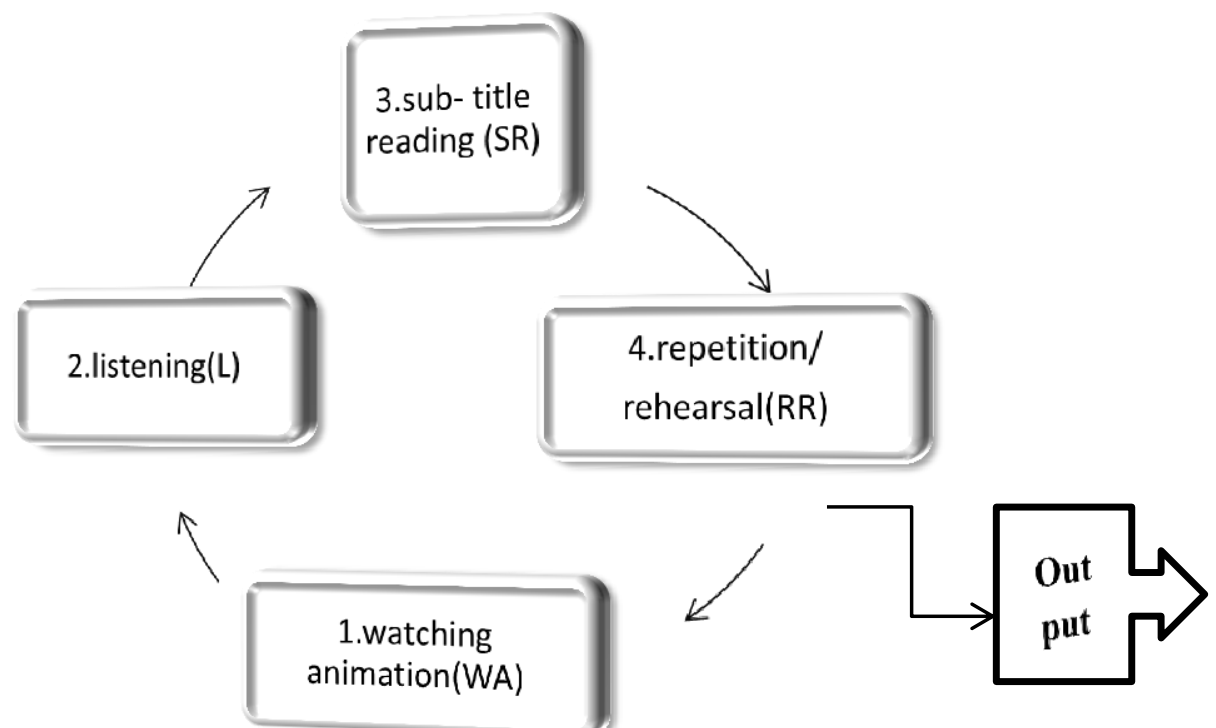

Figure 2. The process of watching animation (WA)-listening (L)-sub title reading (SR)-repetition/rehearsal(RR), continues until learner can take control of their speaking skills WALS3R - cycle

Table 3. The process of dubbing based strategies that teacher follows in her class

10. Teacher turn off the movie sound; muted movie

11. Each learner; based on his voice and characteristic or even feature, take role of the movie characters imitate their voice and repeat that sentences.

12. In muted movie phase ,teacher can cover the subtitle and ask student to say the sentences

13. Because of the dubbing-based nature of the techniques, each learner have to match her voice, features and rhythm of the utterances with the real characters on the movie and even try to present their feeling and emotion

14. Applying the WALS3R - cycle for several times, in order to check and correct learners' pronunciation

15. Recording learners' voice

16. Teacher works not only on the prosodic features of the learners' pronunciation such as stress, intonation and rhythm, but also their speed and fluency 


\section{Discussion and Analysis}

The present study is an attempt to explore the effect of English animation dubbing based techniques on the improvement of the Iranian intermediate EFL learners' native-like pronunciation. The present data were analyzed using independent-samples t-test which assumes normality of the data and homogeneity of variances. Since the ratios of skewness and kurtosis over their standard errors were lower than the absolute value of 1.96 (Table 4), it can be claimed that these data enjoyed normal distribution.

Table 4. Descriptive Statistics; Testing Normality of Data

\begin{tabular}{cccccccccc}
\hline & & $\mathrm{N}$ & \multicolumn{3}{c}{ Skewness } & \multicolumn{3}{c}{ Kurtosis } \\
\cline { 3 - 9 } \multicolumn{2}{c}{ Group } & & Statistic & Statistic & Std. Error & Ratio & Statistic & Std. Error & Ratio \\
\hline \multirow{2}{*}{ experimental } & Pretest & 12 & -.860 & .637 & -1.35 & -.675 & 1.232 & -0.55 \\
& Posttest & 12 & -.944 & .637 & -1.48 & -.537 & 1.232 & -0.44 \\
\hline \multirow{2}{*}{ control } & Pretest & 12 & -.141 & .637 & -0.22 & -1.382 & 1.232 & -1.12 \\
& & Posttest & 12 & -.375 & .637 & -0.59 & -.823 & 1.232 & -0.67 \\
\hline
\end{tabular}

The assumption of homogeneity of variances will be discussed when reporting the main results.

\subsection{Pretest of Pronunciation}

An independent t-test was run to compare the experimental and control groups' means on the pretest of pronunciation in order to prove that they enjoyed the same level of pronunciation ability prior to the main study. Based on the results displayed in Table 5 it can be claimed that the experimental $(\mathrm{M}=85.50, \mathrm{SD}=9.50)$ and the control $(\mathrm{M}=80.42, \mathrm{SD}=8.41)$ groups had almost the same means on the pretest.

Table 5. Descriptive Statistics; Pretest by Groups

\begin{tabular}{cccccc}
\hline & group & $\mathrm{N}$ & Mean & Std. Deviation & Std. Error Mean \\
\hline \multirow{3}{*}{ Pretest } & experimental & 12 & 85.50 & 5.901 & 1.703 \\
& control & 12 & 80.42 & 8.415 & 2.429 \\
\hline
\end{tabular}

The results of the independent $\mathrm{t}$-test $(\mathrm{t}(22)=1.71, \mathrm{p}=.101, \mathrm{r}=.343$ representing a moderate effect size) (Table 6) indicated that there was a non-significant but moderate difference between the two groups means on the pretest of pronunciation. 
Table 6. Independent Samples t-test; Pretest by Groups

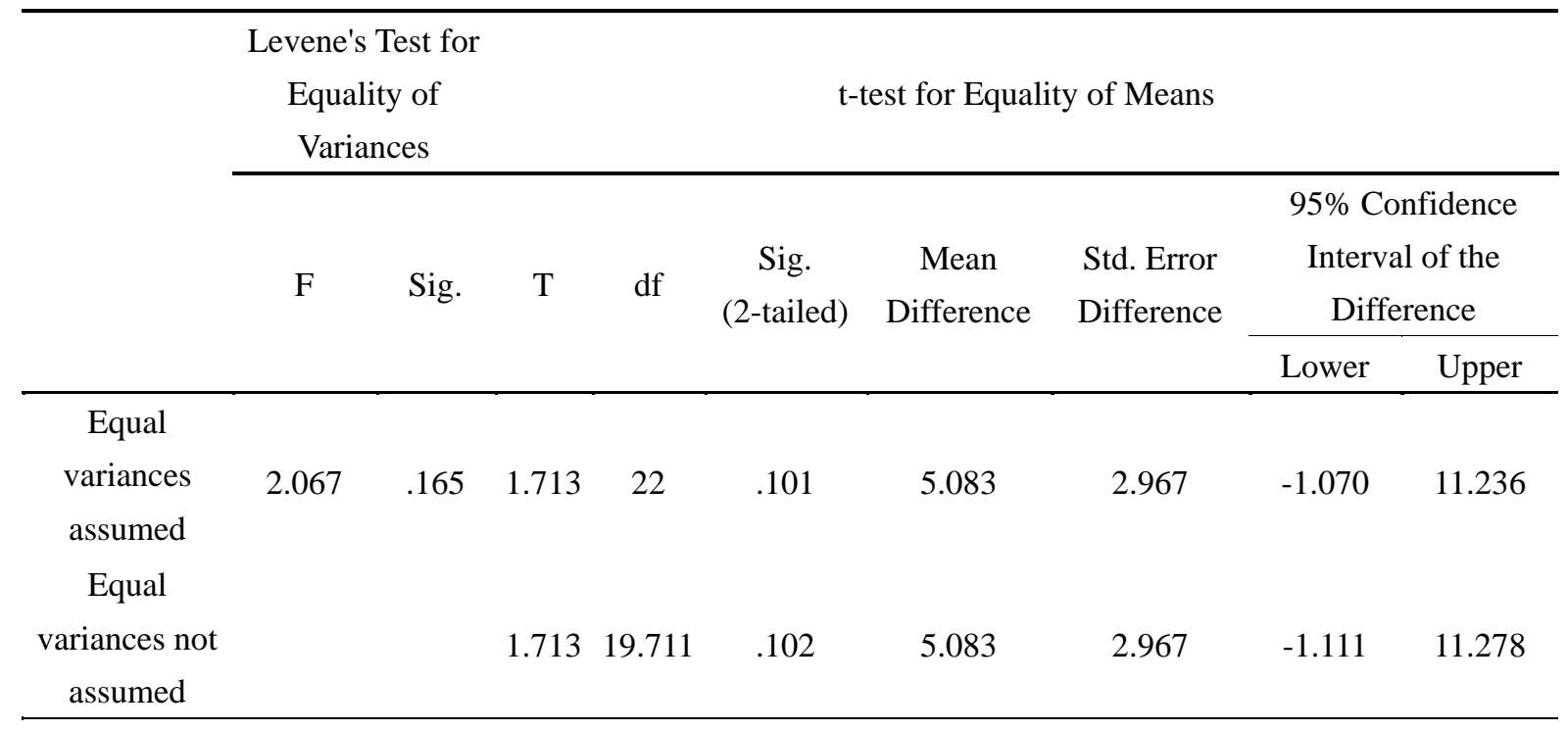

The negative $95 \%$ lower bound confidence interval of -1.07 indicated that the difference between the two groups' means on the pretest could have been zero. Thus the above mentioned conclusion as no significant difference between the two groups' means was correctly made.

It should be noted that the assumption of homogeneity of variances was met (Levene's F = 2.06, $\mathrm{p}=.165)$. That is why the first row of Table 6 i.e. "Equal variances assumed" was reported.

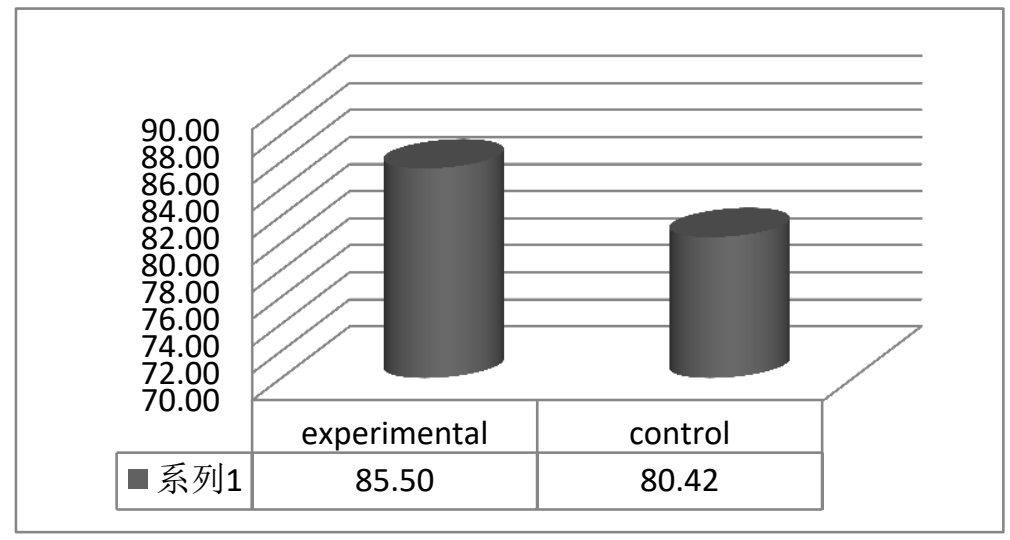

Figure 3. Pretest by groups

\subsection{Posttest of Pronunciation}

An independent t-test was run to compare the experimental and control groups' means on the posttest of pronunciation in order to probe the effect of English animation dubbing based techniques on the improvement of the Iranian intermediate EFL learners' native-like pronunciation. Based on the results displayed in Table 7 it can be claimed that the 
experimental $(M=95.75, S D=4.15)$ had a higher mean than the control $(M=86.33, S D=$ 8.28) group on the posttest.

Table 7. Descriptive Statistics; Posttest by Groups

\begin{tabular}{cccccc}
\hline & Group & $\mathrm{N}$ & Mean & Std. Deviation & Std. Error Mean \\
\hline \multirow{3}{*}{ Posttest } & experimental & 12 & 95.75 & 4.159 & 1.201 \\
& Control & 12 & 86.33 & 8.283 & 2.391 \\
\hline
\end{tabular}

The results of the independent $\mathrm{t}$-test $(\mathrm{t}(22)=3.52, \mathrm{p}=.002, \mathrm{r}=.600$ representing a large effect size) (Table 8) indicated that there was a significant difference between the two groups means on the posttest of pronunciation. Thus the null-hypothesis was rejected.

Table 8. Independent Samples t-test; Posttest by Groups

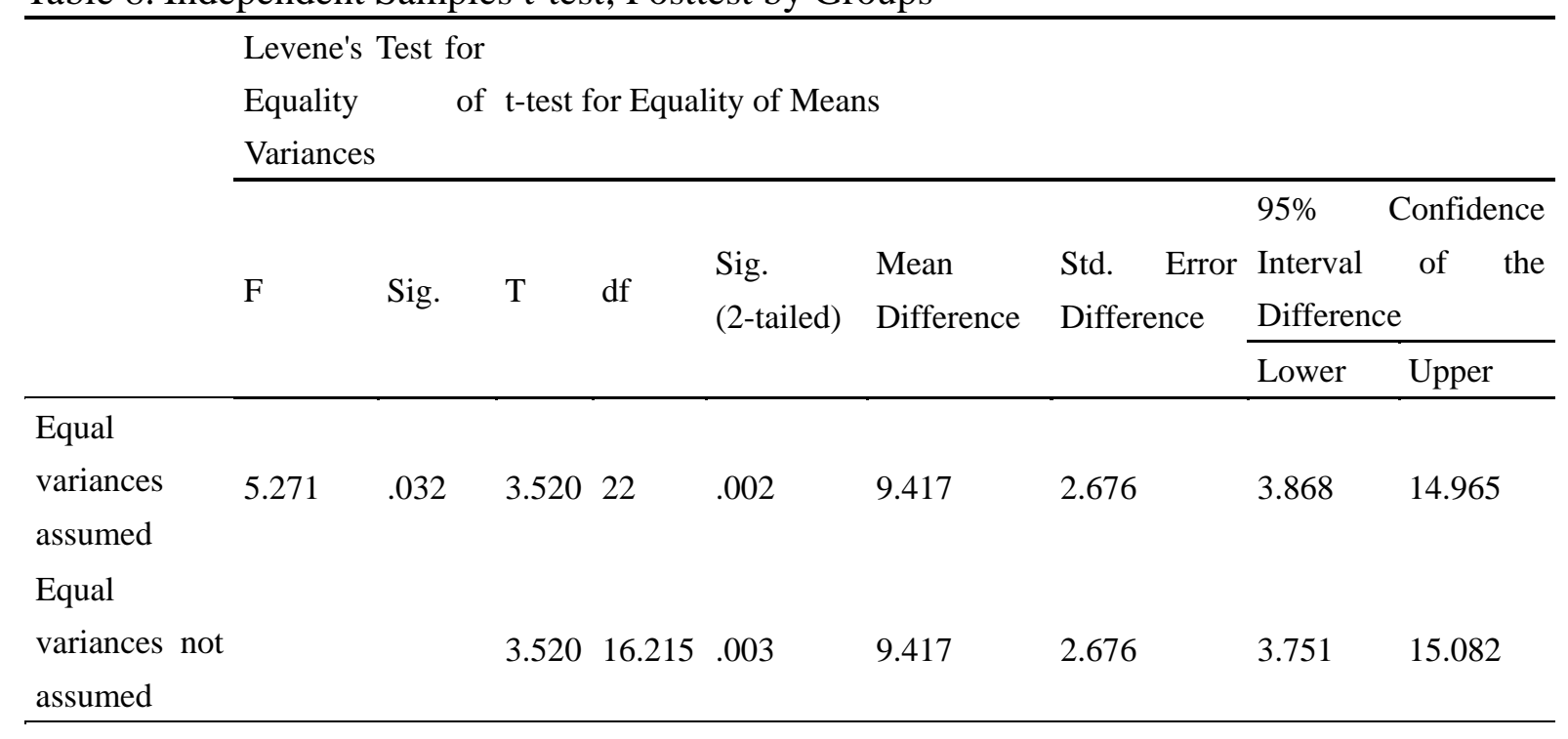

It should be noted that the assumption of homogeneity of variances was not met (Levene's $\mathrm{F}$ $=5.27, \mathrm{p}=.032$ ). That is why the second row of Table 8, i.e. "Equal variances not assumed" was reported.

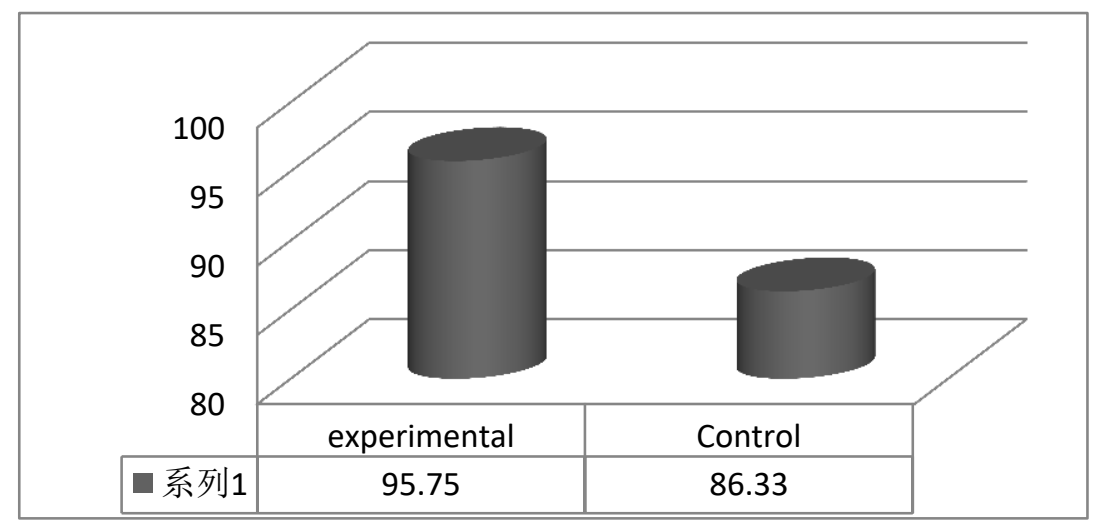

Figure 4. Posttest by groups 


\section{Conclusion}

The present study was an attempt to explore the effect of English animation dubbing based techniques on the improvement of the Iranian intermediate EFL learners' native-like pronunciation. In order to investigate the relationship between dubbing and improved suprasegmental features, 24 homogeneous intermediate 10-15 year old learners were chosen from 40 randomly by an oral test that was divided to two sub groups, i.e, 12 in experimental who received treatment and 12 in control group without that. Students took posttest orally and their performances were recorded. The result was analyzed using independent-samples t-test.

On the pre-test we applied independent t-test to compare the experimental and control group and the results displayed that two groups had the same level of pronunciation ability. It means that there wasn't any considerable difference between two groups.

On the posttest we ran independent t-test to compare two groups again. This time the results displayed that experimental group had a higher mean $(M=95.75)$ than control group $(M=86.33)$. Since there was a significant difference between the mean of two groups on the post test, null hypothesis was rejected and the result of data analysis confirmed the idea that dubbing-based strategies have a significant influence on native like pronunciation development.

Appling different suitable strategies in teaching EFL classroom provides the learners with various opportunity of learning. By using appropriate methods and breaking the chain of the traditional laborious teaching strategies, different kinds of learners regardless of their gender and age can improve their language skills. (Pooneh Karimzadeh, 2016)

\section{Acknowledgment}

Special thanks for my research respectful professor; Dr. Amir Reza Nemat Tabrizi, and the manager of Can DO Institute in Iran; Mr. Otady and Mrs. Momen and my wonderful family. Many thanks for my talented student; Fatemeh Rahimi as a young genius dubber who had a significant role in this research.

\section{References}

Brazil, D., Coulthard, M., \& John, C. (1980). Discourse intonation and language teaching. Lodon:Longman.

Celce-Murcia, M., \& Olshtain, E. (2013). Teaching language through discourse. In M. Celce Murcia, D. M. Brinton, \& M. A. Snow (Eds.), Teaching English as a Second or Foreign Language (4ed, pp. 424-437). Boston, MA: National Geographic Learning/Cengage Learning.

Danan, M. (2010). Dubbing projects for the language learner: A framework for integrating audiovisual translation into task-based instruction. Computer Assisted Language Learning, 23(5), 441-456.

Flege, J. E. (1995). Second language speech learning: Theory, findings, and problems. In W. 


\section{Macrothink}

International Journal of English Language Education

ISSN 2325-0887

2017, Vol. 5, No. 2

Strange (Ed.), Speech perception and linguistic experience (pp. 233-277). Timonium, MD: York Press.

J. Burston. (2005). Video dubbing projects in the foreign language curriculum. Calico Journal.

Javier, Ávila, \& Noa, Talaván. (2013). The role of dubbing in foreign language learning. Universidad Nacional de Educación a Distancia (UNED).

Jones, Rodney H. (1997). Beyond Listen and repeat': pronunciation teaching materials and theories of second language acquisition. System, 25(1), 103-112.

Liu, N., \& Littlewood, W. (1997). Why do many students appear reluctant to participate in classroom learning discourse? System, 25(3), 371-384.

Pennington, M. C. (1989). Teaching pronunciation from the top down. RELK Journal, 20(1), 20-38.

Pennington, M. C. (1989). Phonology in English Language teaching: An international approach. London: Longman.

Pooneh, K. (2016). The effect of drama-based techniques as metacognitive pre-reading strategies on reading comprehension of pre-intermediate Iranian EFL Learners. Research Journal of English Language and Literature, 4(3), 256-267.

Talaván, N. (2013). La subtitulación en el aprendizaje de lenguas extranjeras. Barcelona: Octaedro.

Yi-hui Chiu. (2012). Can film dubbing projects facilitate EFL learners' acquisition of English pronunciation? British Journal of Educational Technology, 43(1), 24-27.

\section{Copyright Disclaimer}

Copyright for this article is retained by the author(s), with first publication rights granted to the journal.

This is an open-access article distributed under the terms and conditions of the Creative Commons Attribution license (http://creativecommons.org/licenses/by/3.0/). 